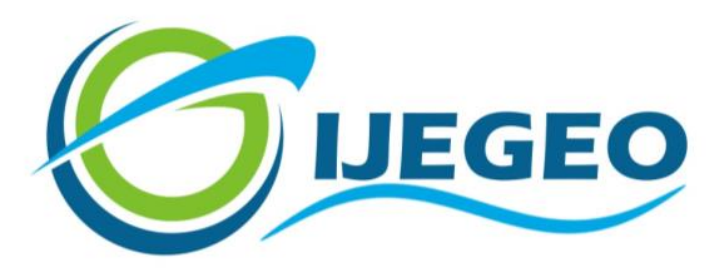

International Journal of Environment and Geoinformatics (IJEGEO) is an international, multidisciplinary, peer reviewed, open access journal.

\title{
Different Test Forms and Numerous Apertures of Cibicidella variabilis (d'Orbigny) from The Turkish Coast of Eastern Aegean Sea
}

\author{
Engin Meriç, Niyazi Avşar, M. Baki Yokeş, Fuat Şaroğlu, Erdoğan Ölmez, \\ İpek F. Barut
}

\section{Editors}

Prof. Dr. Cem Gazioğlu, Prof. Dr. Dursun Zafer Şeker, Prof. Dr. Ayşegül Tanık, Assoc. Prof. Dr. Şinasi Kaya

\section{Scientific Committee}

Assoc. Prof. Dr. Hasan Abdullah (BL), Assist. Prof. Dr. Alias Abdulrahman (MAL), Assist. Prof. Dr. Abdullah Aksu, (TR); Prof. Dr. Hasan Atar (TR), Prof. Dr. Lale Balas (TR), Prof. Dr. Levent Bat (TR), Assoc. Prof. Dr. Füsun Balık Şanlı (TR), Prof. Dr. Nuray Balkıs Çağlar (TR), Prof. Dr. Bülent Bayram (TR), Prof. Dr. Şükrü T. Beşiktepe (TR), Dr. Luminita Buga (RO); Prof. Dr. Z. Selmin Burak (TR), Assoc. Prof. Dr. Gürcan Büyüksalih (TR), Dr. Jadunandan Dash (UK), Assist. Prof. Dr. Volkan Demir (TR), Assoc. Prof. Dr. Hande Demirel (TR), Assoc. Prof. Dr. Nazlı Demirel (TR), Dr. Arta Dilo (NL), Prof. Dr. A. Evren Erginal (TR), Dr. Alessandra Giorgetti (IT); Assoc. Prof. Dr. Murat Gündüz (TR), Prof. Dr. Abdulaziz Güneroğlu (TR); Assoc. Prof. Dr. Kensuke Kawamura (JAPAN), Dr. Manik H. Kalubarme (INDIA); Prof. Dr. Fatmagül Kılıç (TR), Prof. Dr. Ufuk Kocabaş (TR), Prof. Dr. Hakan Kutoğlu (TR), Prof. Dr. Nebiye Musaoğlu (TR), Prof. Dr. Erhan Mutlu (TR), Assist. Prof. Dr. Hakan Öniz (TR), Assoc. Prof. Dr. Hasan Özdemir (TR), Prof. Dr. Haluk Özener (TR); Assoc. Prof. Dr. Barış Salihoğlu (TR), Prof. Dr. Elif Sertel (TR), Prof. Dr. Murat Sezgin (TR), Prof. Dr. Nüket Sivri (TR), Assoc. Prof. Dr. Uğur Şanlı (TR), Assoc. Prof. Dr. Seyfettin Taş (TR), Assoc. Prof. Dr. İ. Noyan Yılmaz (TR), Assist. Prof. Dr. Baki Yokeş (TR), Assist. Prof. Dr. Sibel Zeki (TR), Dr. Hakan Kaya (TR). 


\title{
Different Test Forms and Numerous Apertures of Cibicidella variabilis (d'Orbigny) from The Turkish Coast of Eastern Aegean Sea
}

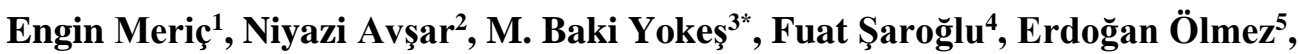 \\ Ípek F. Barut ${ }^{6}$ \\ ${ }^{1}$ Moda Hüseyin Bey Sokak, 15/4, 34710/Kadıköy, Istanbul - TR. \\ ${ }^{2}$ Çukurova Universitesi, Mühendislik Mimarlık Fakültesi, Jeoloji Mühendisliği Bölümü, 01330 Balcalı, Adana - TR \\ ${ }^{3}$ AMBRD Laboratories, Hanımefendi Sokak, 160/6 Şişli 34384, Istanbul - TR \\ ${ }^{4}$ TPAO, M. Kemal Mah. Cad. 86, 06520/Söğütözü, Ankara - TR \\ ${ }^{5}$ MTA Genel Müdürlügü, Jeoloji Dairesi, 06520 Ankara - TR \\ ${ }^{6}$ Istanbul Universitesi, Deniz Bilimleri ve İsletmeciligi Enstitüsü 34134 Vefa, İstanbul, TURKEY Adana - TR
}

\begin{abstract}
In the last ten years, morphological abnormalities and colored tests have been observed in benthic foraminifera specimens collected from Aegean and Southwestern coasts of Turkey. Specific morphological abnormalities show distinct distribution patterns, suggesting the need for special environmental conditions facilitating the development of such abnormalities. Physical and chemical parameters have been proposed to be responsible for these morphological changes.
\end{abstract}

The benthic foraminifera, Cibicidella variabilis (d'Orbigny) specimens have been collected from different locations on the East Aegean coast of Turkey. Some of them, especially those from Dikili Bay, were found to have variable number of apertures, ranging from one to five. These apertures not structurally, but positionally differ. The abundance of certain test forms in specific locations draws attention. The aim of this study is to determine the possible causes of this aberrant morphology observed in tests of Cibicidella variabilis (d'Orbigny).

Cibicidella variabilis (d'Orbigny) shows a wide distribution range on the Aegean coast of Turkey, and has been found in Saros Bay, Gökçeada, Bozcaada, Çanakkale, Edremit Bay, Dikili Bay, Çandarı Bay, Karaburun Peninsula, Kuşadası, Güllük Bay, Gulf of Gökova, Gulf of Datça, and Marmaris Bay. But, the individuals collected from Gulf of Edremit, Dikili Bay, Çandarlı Bay, Gulf of Gökova, and Gulf of Datça were morphologically different than those collected from the rest of the regions. The variation in the number of apertures, as well as their positions were typical in these samples. Besides, the variations in the shape of the tests observed in adult individuals, but not in juveniles indicates that some environmental factors, which were specific to these regions, might have been involved in this unusual test development. The submarine springs caused by the tectonic activities are typical of the Aegean Sea. It is well documented that these kinds of springs change the characteristics of the surrounding habitat and its fauna. Therefore, it is possible that some of the trace elements, which are abundant in hot spring waters, may be related with the abnormal test morphology observed in our samples. On the other hand, it is also possible that, not only the chemical and physical conditions of the surrounding water, but also its biological properties may affect the test development.

Keywords: Cibicidella variabilis, Foraminifera, Eastern Aegean Sea

\section{Introduction}

Temperature, salinity, solubility of calcium carbonate, depth correlation, nutrition, substrate, dissolved oxygen content, illumination, pollution, water motion, trace elements and rapid change in ecological parameters were proposed to be responsible for morphological changes observed on benthic foraminifer tests (Boltovskoy et al., 1991).
Abnormal test development, as well as twins and triplets are commonly observed in natural and artificial saltpans which form hypersaline environments (Almogi-Labin et al, 1992; Stouff et al., 1999; Geslin et al., 2000; Debenay et al., 2001). Contamination by heavy metals are suggested to be one of the major causes of abnormal test morphology of benthic foraminifers. 
The heavy metal source can be either natural or artificial. The heavy metals directly disposed from industrial plants or carried by runoff result in the change in environmental conditions and cause variations on test morphology in benthic foraminifers (Alve, 1991; Sharifi et al., 1991; Yanko et al., 1998 and 1999; Meriç et al. 2002 and 2005). Heavy metal content of the mines which are located near to the coastal regions are washed by runoff and carried to the sea. Such mines are found on the western coast of Turkey (Evans, 1971; Dora and Savaşçın, 1980; Akyürek, 1989; MTA, 1989; Ergin et al, 1993; Ergin and Yemenicioğlu, 1997; Yalçın et al., 2004 and 2008). The high heavy metal concentrations locally affect benthic foraminifera, and are found to cause abnormal test development (Geslin et al., 2002; Meriç et al., 2003; Elberling et al., 2003; Meriç et al., 2008b and 2009).

On the southwestern coast of Turkey, especially around Antalya, agriculture is an important economic sector and chemicals are extensively applied in open fields and greenhouses. The region is karstic, thus bears many groundwater systems, which carry these chemicals to the sea (Meriç et al., 2008b). High amounts of DDT, DDE and DDD have been found in Kirkgöz springs (Northern Antalya) (Ekmekçi, 2005). The high abundance of morphologically abnormal individuals of Textularia bocki Höglund, Peneroplis pertusus (Forskål), P. planatus (Fichtel and Moll), Amphisorus hemprichii Ehrenberg, Sorites orbiculus Ehrenberg, S. variabilis Locroix observed on southeastern coasts of Kas and Kekova (Antalya) supports this hypothesis (Meriç et al., 2008b).

Submarine freshwater and brackish springs can cause extreme seasonal salinity variations in coastal regions which affects benthic foraminifer species and results in the abnormal test development (Nigam et al., 2006; Meriç et al., 2008a). The benthic foraminifer assemblages of the thermal springs were investigated in shallow habitats in the Aegean Sea (Thierman et al., 1997; Varnavas et al. 1999).
Similar studies were conducted around thermal springs in Ilıca Bay - Çeşme (Izmir, western coast of Turkey), without taking the environmental conditions into consideration (Sözeri, 1966; Sellier de Civrieux, 1970). There are also studies which consider the presence of the thermal springs and around (Meriç et al., 2003; Meriç, 1986; Avşar, Meriç, 2001, Meriç, et al., 2015 and Meriç, et al., 2016). In Ilıca Bay there is a submarine thermal spring at $2.5 \mathrm{~m}$ depth with water temperatures of $68^{\circ} \mathrm{C}$ and high radioactivity (Çağlar, 1946; Türkiye Mineralli Su Kaynakları (Ege Bölgesi), 1999; Türkiye Maden Suları (3) Ege Bölgesi, 1974). Specimens of Peneroplis with abnormal morphologies are highly abundant around this spring (Sözeri, 1966; Sellier de Civrieux, 1970).

Cibicidella variabilis (d'Orbigny) is one of the characteristic species of the infralittoral zone in the Mediterranean. It has been reported from various depths between 7-50 m, where Posidonia oceanica meadows dominate (Sgarrella and Moncharmont-Zei, 1993; Cimerman and Langer, 1991). Cibicidella variabilis also inhabits the Aegean Sea and is known to be widely distributed along the Turkish coastline (Meriç and Avşar 2001; Meriç et al., 2002b; Meriç et al., 2002d, Meriç et al., 2004b; Meriç et al., 2003a and b, 2004a, 2005a and b, 2009, Yokeş et al., 2014) (Figure 1).

Cibicidella variabilis (d'Orbigny) shows operculine development, having a trochospiral coiling, with all the whorls visible on the spiral side. The juveniles have one aperture while the adults usually possess two (Cimmerman and Langer 1991, pl. 77, figs. 2-4 and 7-10). The individuals, which have been collected from certain locations on the Aegean coast of Turkey and Italy, were found to have variable number of apertures, ranging from one to five (Sgarrella and Moncharmont-Zei, 1993, pl. 23, figs. 2 and 3; Meriç and Avşar, 2001, pl. 6, figs. 10-12). These apertures do not structurally, but positionally differ. The abundance of certain test forms in specific locations draws attention. The aim of this study is to figure out the possible causes of this aberrant test morphology observed in Cibicidella variabilis (d'Orbigny) individuals. 
The Aegean coast of Turkey, enclosed by the south, has been investigated in the scope of Gökçeada to the north, and Marmaris Bay to this study

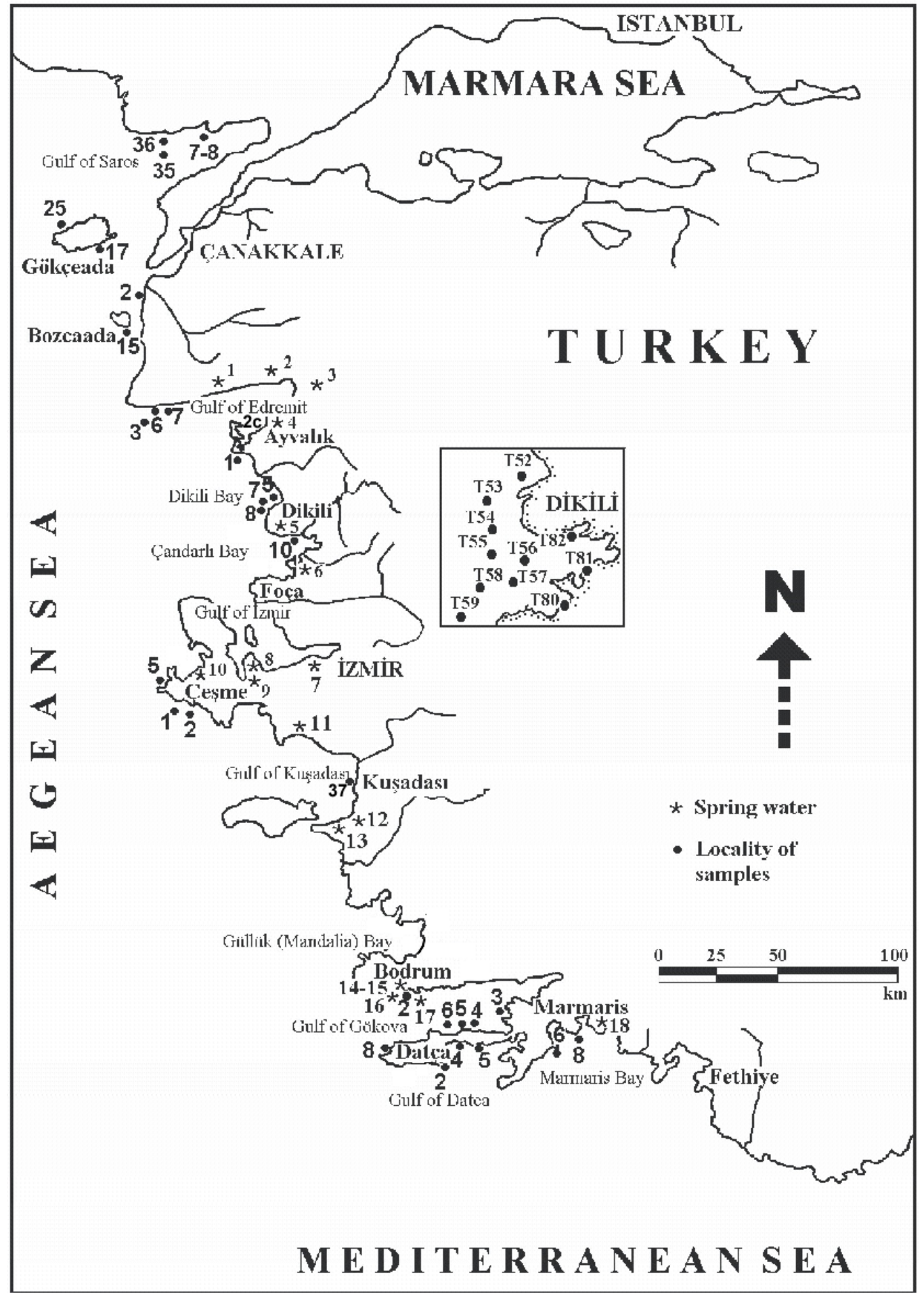

Figure 1. Locations of the sampling stations and major terrestrial and submarine thermal springs on the Aegean coast of Turkey. 


\section{Systematic Paleontology}

Family Planorbulinidae Schwager, 1877

Subfamily Planorbulininae Schwager, 1877

Genus Cibicidella Cushman, 1927

\section{Cibicidella variabilis (d'Orbigny)}

(Pl. 1, figs. 1-14; pl. 2, figs. 1-14; pl. 3, figs. 1-6)

1839 Truncatulina variabilis d'Orbigny. P. 135, pl. 2, fig. 29.

1896 Truncatulina variabilis d'Orbigny. Dezelic, p. 87.

1931 Cibicidella variabilis (d'Orbigny). Cushman, p. 127, pl. 24, fig. 3.

1974 Cibicidella variabilis (d’Orbigny). Colom, p. 150, figs. 33, 34.

1974 Cibicidella variabilis (d’Orbigny). Le Calvez, Y., p. 96, pl. 26, figs. 1-4.

1979 Cibicidella variabilis (d'Orbigny). Blanc-Vernel et al., pl. 23, fig. 3.

1988 Planorbulina variabilis (d'Orbigny). Loeblich and Tappan, p. 588, pl. 645, figs. 5-6.

1991 Cibicidella variabilis (d'Orbigny). Cimerman and Langer, p. 72, pl. 77, figs. 1-10.

1993 Cibicidella variabilis (d'Orbigny). Sgarrella and Moncharmont-Zei, p. 234, pl. 22, figs. 10-11.

2001 Cibicidella variabilis (d'Orbigny). Meriç and Avşar, pl. 6, figs. 10-12.

2004a Cibicidella variabilis (d'Orbigny). Meriç et al., p. 186, pl. 28, figs. 6-11.

\section{Materials and Methods}

Sediment samples have been collected by Van Veen Grab dredge from different locations in Saros Bay, Gökçeada, Bozcaada, Edremit Bay, Dikili Bay, Çandarlı Bay, west of Karaburun Peninsula, Kuşadası, Güllük Bay, Gökova, Datça and Marmaris. Unfortunately, physical and chemical parameters, except for the depth and the coordinates, had not been recorded during sampling. The depths of the stations ranged between 15.0 and $230.0 \mathrm{~m}$ (Figure 1 and Table 1).

For heavy metal analysis $0.2-0.5 \mathrm{~g}$ of sediment was weighed and dissolved with $4 \mathrm{ml}$ of HNO3 for 4 minutes in HACH2 digesdake. Then $15 \mathrm{ml}$ of $\mathrm{H} 2 \mathrm{O} 2$ was added.

The volume of dissolved sample was diluted to $10 \mathrm{ml}$. The concentrations of heavy metals in the sediment samples were measured by a flame spectrometer. The heavy metals analyzed were $\mathrm{Pb}, \mathrm{Cr}, \mathrm{Ni}, \mathrm{Co}, \mathrm{Cu}, \mathrm{Mn}$ and $\mathrm{Fe}$. No trace of $\mathrm{Cd}$ was detected. In many samples $\mathrm{The} \mathrm{Pb}$ values were not measured.

\section{Results}

Cibicidella variabilis (d'Orbigny) specimens have been collected from various stations. The samples show variable test morphologies. Morphological abnormalities include test abnormalities and chamber abnormalities, the location of the apertures differ among individuals and the number of apertures vary between one and five (Plate 1-3).

However, the specimens obtained from the 8th station in Dikili-Çandarlı region show the most diverse and highest abundance of abnormal tests. Especially the aberrant chamber formations on the spiral side and the positions of the second, third, fourth and fifth apertures constitute the main differences compared to the individuals observed elsewhere.

Heavy metals such as $\mathrm{Pb}, \mathrm{Cr}, \mathrm{Ni}, \mathrm{Cu}, \mathrm{Co}, \mathrm{Mn}$ and $\mathrm{Fe}$ were found in the sediment analysis (Tables 2 and 3) 
Table 1. Water depths of the stations.

\begin{tabular}{|c|c|c|}
\hline Location & Station no & Depth (m) \\
\hline Gökçeada & 2 & 32.4 \\
\hline \multirow{3}{*}{ Edremit Bay } & 3 & 230.0 \\
\hline & 6 & 15.0 \\
\hline & 7 & 19.0 \\
\hline \multirow{5}{*}{ Dikili-Çandarlı } & 1 & 16.0 \\
\hline & 5 & 18.0 \\
\hline & 7 & 35.0 \\
\hline & 8 & 35.8 \\
\hline & 10 & 22.5 \\
\hline Çeşme-İzmir & 5 & 18.0 \\
\hline \multirow{2}{*}{ Kuşadası } & 1 & 73.0 \\
\hline & 2 & 31.3 \\
\hline \multirow{6}{*}{ Gulf of Gökova } & 2 & 27.0 \\
\hline & 3 & 80.4 \\
\hline & 4 & 46.2 \\
\hline & 5 & 34.5 \\
\hline & 6 & 65.0 \\
\hline & 8 & 78.3 \\
\hline \multirow{3}{*}{ Gulf of Datça } & 2 & 45.0 \\
\hline & 4 & 40.0 \\
\hline & 5 & 59.3 \\
\hline \multirow{2}{*}{ Marmaris Bay } & 6 & 64.0 \\
\hline & 8 & 69.0 \\
\hline
\end{tabular}

Table 2. Heavy metal concentrations of the sediments from Dikili Bay.

\begin{tabular}{|c|c|c|c|c|c|c|c|}
\hline Station & $\mathbf{P b} \boldsymbol{\mu g} / \mathbf{g}$ & $\mathbf{C r} \boldsymbol{\mu g} / \mathbf{g}$ & $\mathbf{N i} \boldsymbol{\mu g} / \mathbf{g}$ & $\mathbf{C u} \boldsymbol{\mu g} / \mathbf{g}$ & $\mathbf{C o} \boldsymbol{\mu g} / \mathbf{g}$ & $\mathrm{Mn} \boldsymbol{\mu g} / \mathbf{g}$ & $\mathbf{F e} \boldsymbol{\mu g} / \mathbf{g}$ \\
\hline 2 & --- & 6,65 & 0,06 & 1,05 & 0,58 & 59 & 140,11 \\
\hline 3 & 0,73 & 8,99 & 3,7 & 5,28 & 1,79 & 73,65 & ---- \\
\hline 4 & ---- & 6,39 & 4,75 & 6,66 & 7,98 & 23,74 & 297,18 \\
\hline 5 & 0,47 & 17,64 & 5,71 & 29,56 & 1,77 & 87,24 & ---- \\
\hline 8 & 0,03 & 9,81 & 2,54 & 4,28 & 1,49 & 56,57 & 268,691 \\
\hline
\end{tabular}


Table 3. Heavy metal concentrations in surface sediments from the Dikili and Çandarlı bays (from Ergin et al., 1993)

\begin{tabular}{|c|c|c|c|c|c|c|c|}
\hline Station & $\mathbf{Z n} \boldsymbol{\mu g} / \mathbf{L}$ & $\mathbf{C r} \boldsymbol{\mu g} / \mathbf{L}$ & $\mathbf{N i} \boldsymbol{\mu g} / \mathbf{L}$ & $\mathbf{C u} \boldsymbol{\mu g} / \mathbf{L}$ & $\mathbf{C o} \boldsymbol{\mu g} / \mathbf{L}$ & $\mathbf{M n} \boldsymbol{\mu g} / \mathbf{L}$ & $\mathbf{F e} \%$ \\
\hline T52 & 19 & 9 & 13 & 3 & 2 & 103 & 0.59 \\
\hline T53 & 27 & 32 & 30 & 6 & 7 & 172 & 1.18 \\
\hline T54 & 37 & 42 & 36 & 11 & 5 & 441 & 2.20 \\
\hline T55 & 81 & 73 & 43 & 34 & 9 & 352 & 3.07 \\
\hline T56 & 58 & 58 & 35 & 14 & 12 & 377 & 3.58 \\
\hline T57 & 98 & 103 & 118 & 27 & 19 & 716 & 4.23 \\
\hline T58 & 84 & 161 & 70 & 16 & 12 & 704 & 2.98 \\
\hline T59 & 53 & 68 & 62 & 11 & 9 & 388 & 2.58 \\
\hline T80 & 93 & 101 & 50 & 21 & 12 & 337 & 3.16 \\
\hline T81 & 56 & 65 & 36 & 16 & 9 & 269 & 2.99 \\
\hline T82 & 60 & 74 & 52 & 18 & 9 & 343 & 3.69 \\
\hline
\end{tabular}

In Sample 3 and 5, elevated levels of $\mathrm{Pb}$ was observed; however, no Fe was found, and also other heavy metals like $\mathrm{Cr}, \mathrm{Ni}, \mathrm{Cu}, \mathrm{Co}$ and $\mathrm{Mn}$ were measured under the shale values (Krauskopf, 1985), but still having considerable values. The amounts of $\mathrm{Mn}, \mathrm{Cr}$ and $\mathrm{Cu}$ in the Sample 2, 4 and 8 deserve attention. Yet, the Sample 5 shows the highest $\mathrm{Mn}, \mathrm{Cr} ; \mathrm{Cu}$ and $\mathrm{Ni}$ concentrations among the samples.

\section{Discussion}

The water temperature in the Eastern Aegean Sea has been found to vary between $9-26^{\circ} \mathrm{C}$ and the oxygen concentration has been observed as 4-10ml/1 (Artüz 1970; Benli and Küçüksezgin, 1988; Ergin et al, 1993), indicating that the continental shelf, including the area of interest, was an environment with aerobic conditions.

During the Middle Miocene, an expansion had been started in this area by the collision of the Arabian and Anatolian plates. The Northern and Eastern Anatolian Faults had been formed because of the pressure exerted by this collision (Şengör and Y1lmaz, 1981). The Anatolian Plate which is situated between these faults had moved towards the west. As a result, east-towest oriented graben systems had been formed in the Aegean region (Figure 2) (Arpat and Şaroğlu, 1975; McKenzie, 1977; Turgut, 1987; Mascle and Martin, 1990; Y1lmaz, 1990). These grabens are restricted with the active and normal faults that are known to be the sources of thermal springs.
Numerous thermal springs have been known from the Aegean coast of Turkey (Figure 1; Table 4).

The major springs of the Gulf of Edremit are: Kucukçetmi (1) and Güre (2) on the north, Bostanc1 (3) on the east and Zeytinpinari (4) on the southeast (Meriç et al., 2003a, Meriç et al., 2003a). Based on the foraminifer data obtained, especially from the northern part of the Gulf of Edremit, several submarine springs were suggested to be on the fault lines on the sea bottom. Bademli (5) on the south of Dikili and Ilicaburun (6) on the northwest of Aliağa are the two popular hot springs located in the vicinity of Dikili and Çandarl1. The major thermal springs located in İzmir are Balçova (7), Urla (8), Gülbahçe (9), Şifne (10) and Doğanbey (11) springs. There are many more springs found on the shoreline on the south of İzmir, which Kuşadası (12) and Güzelçamlı (13) in Davutlar; Içme (14), Tavşanburnu (15), Karaada (16), Orakada (17) in the Gokova Bay; and Sultaniye (18) in Köyceğiz are the most known examples (Barut, 2001).

Hydrothermal springs are also observed in different locations on the southeast of Greece, such as on the Milos, Yali and Kos Islands, as well as in many bays of the Methana Peninsula which is located on the Hellenic Volcanic Arc (Varnavas et al., 1999). Coastal and marine faults are common on both side of the Aegean Sea. Especially the two fault lines situated on the east and south of Lesbos Island worth to pay attention. The salty waters of numerous thermal springs with variable temperature ranging between $39-69^{\circ} \mathrm{C}$ indicate that these springs are related to the marine fault lines. 
Cibicidella variabilis (d'Orbigny) shows a wide distribution in the Eastern Aegean coats of Turkey, mainly in the infralittoral and upper circalittoral zones, and rarely in lower circalittoral and upper epibathyal zones (Meriç et al., 2004b). It has been recorded from Gulf of Saros, and Harmantaşı locality, Gökçeada, Bozcaada, Gulf of Edremit, Dikili and Çandarlı Bays, Gulf of İzmir and vicinity of Karaburun Peninsula, Gulf of Kuşadası and Güllük Bay, Gulf of Gökova, Gulf of Datça, Marmaris Bay and southwestern coast of Antalya. However, the specimens that are observed in 5 different areas in Gulf of Edremit, Dikili Bay, Çandarlı Bay, Gulf of Gökova and Gulf of Datça present different test structures.
None of the specimens collected from SW Antalya had abnormal test morphology, however, 50-60\% of the Cibicidella variabilis (d'Orbignyi) population show aperture abnormalities in Dikili Bay. The abnormal individuals are especially abundant in Gikili Bay and Gulf of Gökova. The presence of hot and cold water springs, which result from the young tectonic activity (Figure 2), can be discussed as the most important factor (Çağlar, 1947; Başkan and Canik, 1983; Thierman et al., 1997; Varnavas et al., 1999; Meriç and Avşar, 2001; Avşar and Meriç, 2001; Meriç et al., $2002 \mathrm{a}, \mathrm{b}, \mathrm{c}$ and d). Since these types of springs change the environmental conditions, faunal differences are observed in the vicinity of these submarine springs. (Meriç and Avşar, 2001; Meriç et al., 2004b).

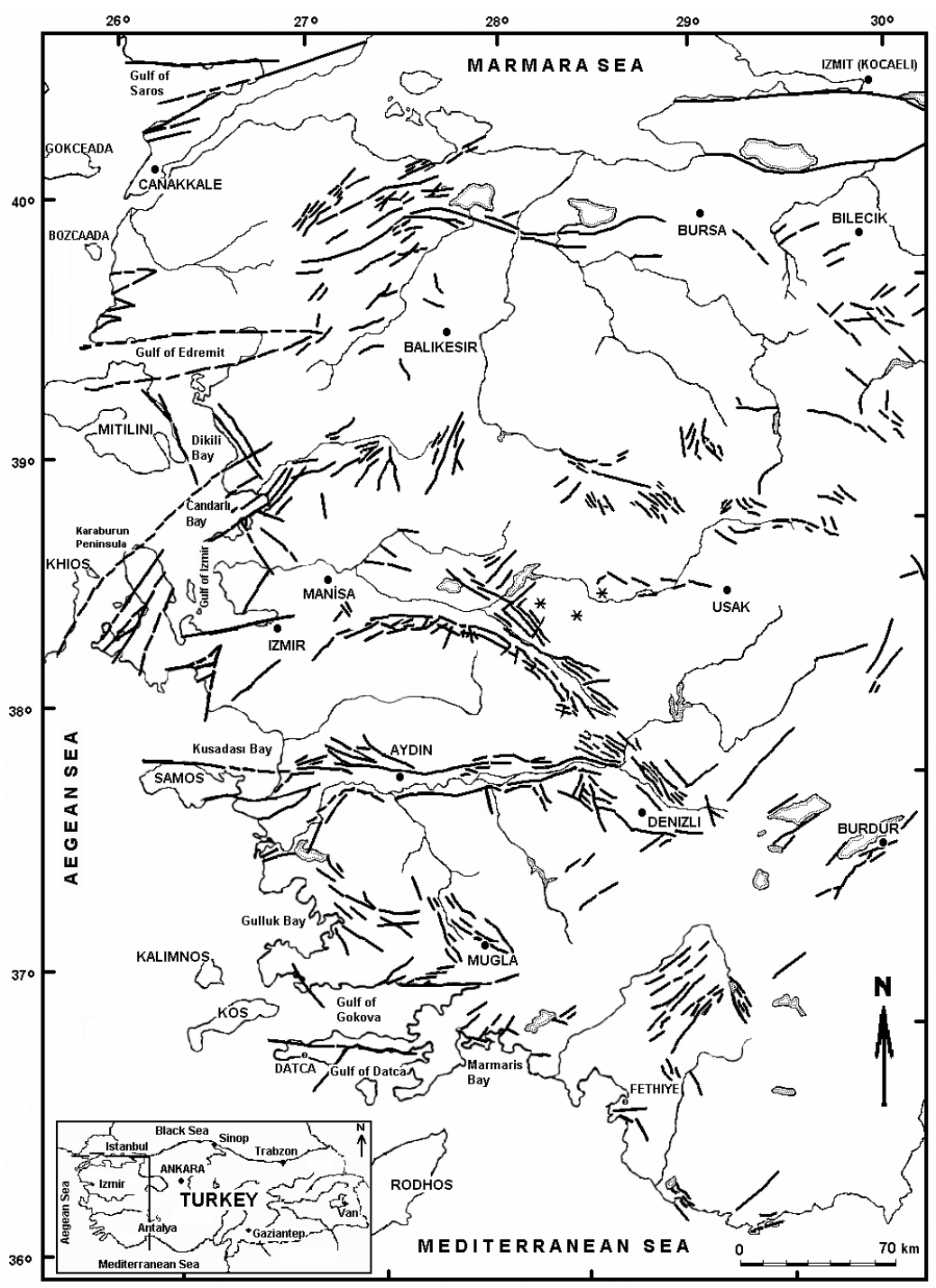

Figure 2. Major fault systems of the Western Anatolia. 
Table 4. Physical and chemical properties of the spring waters from the Western Anatolia, the dates of records are indicated in parentheses (Türkiye Maden Suları 3, 1974; Türkiye Mineralli Su Kaynakları I, 1999).

\begin{tabular}{|c|c|c|c|c|c|c|c|c|c|c|c|}
\hline $\begin{array}{l}\text { Quality of } \\
\text { Phisical and } \\
\text { chemical }\end{array}$ & $\begin{array}{c}\text { DíkíLi- } \\
\text { BADEMLİ } \\
\text { (1974) }\end{array}$ & $\begin{array}{c}\text { DíKíLi- } \\
\text { BADEMLİ } \\
\text { (1995) }\end{array}$ & $\begin{array}{c}\text { ALİAĞA- } \\
\text { ILICABURUN } \\
\text { (1995) }\end{array}$ & $\begin{array}{l}\text { GÜRE } \\
\text { (1974) }\end{array}$ & $\begin{array}{l}\text { GÜRE } \\
\text { (1947) }\end{array}$ & $\begin{array}{c}\text { BOSTANCI } \\
(1947)\end{array}$ & $\begin{array}{c}\text { ZEYTIN } \\
\text { PINARI } \\
\text { (1947) }\end{array}$ & $\begin{array}{c}\text { KÜÇÜK } \\
\text { ÇETMİ } \\
\text { (1947) }\end{array}$ & $\begin{array}{c}\text { TAVŞAN } \\
\text { BURNU } \\
\text { (1971) }\end{array}$ & $\begin{array}{c}\text { KARAADA } \\
\text { (1971) }\end{array}$ & $\begin{array}{c}\text { SULTANIYE } \\
\text { (1971) }\end{array}$ \\
\hline $\begin{array}{c}\text { Temperature } \\
\left({ }^{\circ} \mathbf{C}\right)\end{array}$ & 42 & 59 & 51,4 & 59 & 53 & 59,5 & 20 & 41 & 22 & 33 & 32 \\
\hline $\mathbf{P H}$ & 6,24 & 6,61 & 6,72 & 8,48 & & 7,2 & 6,2 & 6,4 & 7,1 & 6,38 & 6,74 \\
\hline $\mathrm{EC}(\mu \mathrm{s} / \mathrm{cm})$ & 10500 & 25000 & 48400 & $\begin{array}{l}7,52 \\
10^{-4}\end{array}$ & & & & & 0,1 & 0,11 & 0,05 \\
\hline Stream (l/s) & 2 & & & & & & & & 0,6 & 20 & \\
\hline $\mathbf{R n}^{222}($ Bekerel $)$ & 399,9 & & & 11,1 & 14,8 & 42,6 & 41,8 & 23,7 & 59,57 & 86,95 & 3349,24 \\
\hline $\mathrm{NH}_{4}^{+}(\mathrm{mg} / \mathrm{l})$ & 5,15 & 6,250 & 4,34 & 0,39 & trace & 1,7 & & & - & - & - \\
\hline $\mathrm{Na}^{+}(\mathrm{mg} / \mathrm{l})$ & 2634,1 & 2630,1 & 6322,25 & 284,04 & 279,7 & 161,9 & 2473,5 & 156 & 1771,79 & 11960 & 5320,81 \\
\hline $\mathrm{K}^{+}(\mathrm{mg} / \mathrm{l})$ & 246,5 & 187,68 & 262,75 & 6,65 & 13,5 & 21,2 & 36,1 & 15,8 & 112,23 & 277,29 & 205,47 \\
\hline $\mathrm{Ca}^{2+}(\mathrm{mg} / \mathrm{l})$ & 251,29 & 128 & 701,6 & 23,98 & 23,2 & 46,6 & 550,8 & 38,7 & 288,96 & 1335,04 & 940 \\
\hline $\mathrm{Mg}^{2+}(\mathrm{mg} / \mathrm{l})$ & 82,76 & 72,9 & 643,95 & 0,54 & 2,4 & 10 & 570,6 & 9 & 202,08 & 1162,12 & 421,84 \\
\hline $\mathrm{Fe}^{2+}(\mathrm{mg} / \mathrm{l})$ & 0,65 & 2,16 & 0,79 & & 0,12 & 0,07 & trace & 0,11 & 0,28 & 1,3 & 0,68 \\
\hline $\mathrm{Al}^{3+}(\mathrm{mg} / \mathrm{l})$ & 0,39 & 0,24 & 0,1 & 0,55 & 2,88 & 2,2 & 1,65 & 1,7 & 0,09 & 0,65 & 0,38 \\
\hline $\mathrm{Cl}^{-}(\mathrm{mg} / \mathrm{l})$ & 4433,2 & 4115,75 & 11436,91 & 70 & 84,8 & 100 & & 74,2 & 3300 & 21900 & 9800 \\
\hline$I^{-} \quad(\mathrm{mg} / \mathrm{l})$ & 0,15 & 0,15 & 0,8 & 0,02 & & & & & 0,02 & 0,06 & 0,07 \\
\hline $\mathrm{Br}^{-}(\mathrm{mg} / \mathrm{l})$ & & 0,012 & 14,5 & & & & & & 3,9 & 11,9 & 6,4 \\
\hline $\mathrm{Fl}^{-}(\mathrm{mg} / \mathrm{l})$ & 2,16 & 2,15 & 2,45 & 5,72 & & & & & 1,5 & 3,75 & 1,95 \\
\hline $\mathrm{SO}_{4}{ }^{2-}(\mathrm{mg} / \mathrm{l})$ & 200 & 262,5 & 1625 & 543 & 489,1 & 323,5 & 937,4 & 49,4 & 510 & 2920 & 1770 \\
\hline $\mathrm{NO}_{3}^{-}(\mathrm{mg} / \mathrm{l})$ & 0,27 & 0,33 & 4,2 & 1,78 & & trace & & & 0,14 & & 0,09 \\
\hline $\mathrm{CO}_{3}^{-}(\mathrm{mg} / \mathrm{l})$ & - & 0 & 0 & 9,6 & 18 & & & & - & - & - \\
\hline $\mathrm{HCO}_{3}^{-}(\mathrm{mg} / \mathrm{l})$ & 683,2 & 694,36 & 798 & 3,61 & 61 & 61,5 & 174,4 & 422,7 & 433,1 & 658,8 & 302,56 \\
\hline $\mathrm{HAsO}_{4}{ }^{2}(\mathrm{mg} / \mathrm{l})$ & 0,12 & 0,11 & 0,012 & 0,02 & & & & & 0,09 & 0,28 & 0,28 \\
\hline $\mathrm{H}_{2} \mathrm{SiO}_{3}(\mathrm{mg} / \mathrm{l})$ & 150,8 & 122,38 & 1,1 & 71,5 & 52 & 110,5 & 23,4 & 52 & - & 2,25 & 1,47 \\
\hline $\mathrm{HBO}_{2} \quad(\mathrm{mg} / \mathrm{l})$ & 95,07 & 93,14 & 4,8 & 15,8 & & & & & 6,72 & 21,14 & 4,78 \\
\hline $\mathrm{H}_{2} \mathrm{~S} \quad(\mathrm{mg} / \mathrm{l})$ & & & & 1,12 & 1,6 & & & & - & - & 8,2 \\
\hline
\end{tabular}


Rich foraminifer populations were observed on the northeast of Gökçeada, in Dikili Bay (8), Gulf of Gökova $(2,6)$ and also in Gulf of Datça $(4,5)$. The observance of Peneroplis pertusus (Forskål), P. planatus (Fichtel and Moll) and Amphistegina lobifera Larsen in the 4th station of Gulf of Datça proves that the ecological conditions in these locations should be different compared to the other regions. The observation of a large amount of Cibicidella variabilis (d'Orbigny) with different test structures in the sediment sample obtained from the 8th station in Dikili Bay can be considered as another proof of this idea (Pl. 1,). Yet, the rich Peneroplis population around the thermal spring in Ilica Bay (Meriç, 1986; Avşar and Meriç, 2001) and the morphological anomalies that is seen among their tests (Sözeri, 1966; Sellier de Civrieux, 1970) suggests that the environmental conditions of the thermal springs are involved in the formation of such tests. Some previously published studies also support this idea. Another Cibicidella variabilis (d'Orbigny) specimen from northwest of Gökçeada have well developed but elongated adult chambers (Meriç and Avşar 2001, pl. 6, fig. 12). While the three Cibicidella variabilis (d'Orbigny) individuals collected from two different stations in the Aegean Sea have normal test morphology (Pl. 1, figs. 10-11; Pl. 2, fig. 1), the others show abnormal development (Pl. 2, figs. 9, 10, 12 and Pl. 3, fig. 1).

In addition to these findings, some $C$. variabilis samples from Volcano Island, Tyrrhenian Sea (Cimerman and Langer, 1991, pl. 77, figs. 3, 4, $7,8)$ were also found to differ in test morphology. The number of apertures as well as their positions suggests a regional variety, since the other two Cibicidella variabilis (d'Orbigny) specimens (Cimerman and Langer, 1991, pl. 77, figs. 5 and 6), as well as the two specimens from the Ischia and Procida Islands show usual test morphology (Sgarrella and Montcharmont-Zei, 1993; pl. 23, Figs. 2 and 3). Cibicidella variabilis (d'Orbigny) individuals usually have two apertures (Cimerman and Langer, 1991, pl. 77, figs 9 and 10; Meriç and Avşar, 2001, pl. 6, fig. 11), but, a total of four apertures are observed in one specimen from Volcano Island. One of the apertures is located on the final chamber, and the other three are positioned side by side in the center of the test (Cimerman and Langer, 1991, pl. 77, figs. 7 and 8).
Similar aperture characteristics are also observed in a specimen collected from Station 2 in Gulf of Gökova, which has four apertures, separately positioned in groups of two (Pl. 2, figs. 3-5). When the structures of the chambers are taken into consideration, another sample from Vulcano Island (Cimerman and Langer, 1991, pl. 77, fig. 4) is found to be very similar with the two individuals collected from Gulfs of Datça and Edremit (Pl. 1. figs. 9-10). The occurrence of similar aberrant test forms and their abundance in certain distant localities suggest that this kind of irregular chamber development may have a common mechanism caused by a specific environmental condition.

Mine fields are found around Gulfs of Gökova and Datça, moreover, high levels of heavy metals are recorded in the recent sediments from Dikili Bay (Figure 1). Ergin et al. (1993), has specified the presence of heavy metals such as $\mathrm{Fe}, \mathrm{Mn}, \mathrm{Co}, \mathrm{Cr}$, $\mathrm{Cu}, \mathrm{Ni}$, and $\mathrm{Zn}$. Although these results are not generally in line with our data, the harmony between the $\mathrm{Cu}$ and $\mathrm{Co}$ values in the sediment samples bears attention. The differences can be explained by different depths of sampling points and the different techniques of analysis. No rivers that have the capacity to carry sediments are present in these regions apart from the Madra Stream in northern part of Dikili.

The reason for observing such considerably high values of heavy metals can be discussed as the interference of subterranean water with the nearby rocks and the presence of submarine thermal springs. Yet the presence of a high number of such thermal springs in northeast Lesbos Island supports this idea. When the foraminifer composition of the analyzed samples is taken into consideration, variable number of species are observed in different sediment samples; 1 (40), 2 (55), 3 (48), 4 (10), 5 (56), 6 (24), 7 (37), 8 (68) and 9 (36), which suggests that different ecological conditions might prevail in these stations.

Some benthic foraminifer genera and species that are found in East Aegean Turkish coasts, such as Asterigerinata mamilla (Willamson), Cibicides refulgens Montfort, Cyclocibides vermiculatus (d'Orbigny), Elphidium aculeatum (d'Orbigny), E. crispum (Linné), E. macellum (Fichtel and Moll), 
Nubecularia lucifuga Defrance, Peneroplis pertusus (Forskal), P. planatus (Fitchel and Moll), Planorbulina mediterranensis d'Orbigny, Quinqueloculina disparilis d'Orbigny, $Q$. laevigata d'Orbigny, $Q$. lamarckiana d'Orbigny, Rosalina bradyi Cushman, $R$. globularis d'Orbigny, Sorites orbiculus Ehrenberg, Textularia agglutinan d'Orbigny, Triloculina schreiberiana d'Orbigny and Vertebralina striata d'Orbigny live epiphytically on algae and plants like Posidonia oceanica (Linnaeus) Delile, Ectocarpus sp. and Udotea petiolata (Turra) Børgesen. However, no morphological change was observed in the specimens of the above mentioned species except Lobatula lobatula (Walker and Jacob) on the East Aegean Turkish coasts. In the Lobatula lobatula (Walker and Jacob) specimens, which were collected from different locations with variable depths on the Turkish coastline, the observed morphological variations were in accordance with those from other studies. In the study that was conducted by Hallock (1984) in the Western Caroline Islands and in Hawaii (Pacific Ocean), which can be stated as a farther region, some specific examples as to the foraminifers living on algae are given.

Different foraminifer genera and species that were collected from these two regions, such as Peneroplis pertusus (Forskål), P. planatus (Fichtell and Moll) and Amphistegina lobifera Larsen, which are also found in the Eastern Aegean Sea, were always found in high numbers, but no morphological variations were observed.

Three groups of apertures were observed in one of the Peneroplis planatus (Fichtel and Moll) specimens collected from Gulf of Edremit, showing aperture morphology of both Peneroplis and Coscinospira genera (Meriç et al., 2005b, fig. 6f). Five groups of apertures were observed in a Penereplis pertusus (Forskål) specimen collected from the southwestern coast of Bozcaada (Meriç et al., 2005, fig. 6e). Many Cibicidella variabilis (d'Orbignyi) Peneroplis pertusus (Forskål), Peneroplis planatus (Fichtel and Moll) individuals are observed in Ayvalik, showing abnormal coloration and test morphology, but not aperture (unpublished data).
It is not possible to link this incident to the surface characteristics of the algae on which these foraminifers live. Because, some of the samples from Volcano Island were derived from normal sediments and some were from Posidonia meadows (Langer, 1988).

This runs counter to the hypothesis about the link of the morphological changes of foraminifers with the algae they live on. Likewise, the presence of islands that were formed as a result of recent volcanisms around Volcano Island in the South Tyrrhenian Sea and islands that were formed as a result of young tectonic activity in the North Adriatic Sea, like in the Aegean Sea, and the presence of submarine thermal springs that are formed as a result of young fault lines in the region can be considered as the main reason of the development of Cibicidella variabilis (d'Orbigny) with similar characteristics in different locations. (see Cimerman and Langer, 1991, pl. 77, figs. 3, 4, 7 and 8) Different environmental factors can have different effects on different genera and specimen of foraminifers (Meriç et al., 2002c).

One of the most important factors that bear attention in the samples that were derived from East Aegean Sea coasts is the high number of apertures. This number can vary from 1 to 5 (Pl. 3, figs. 2-6). Another aspect to take into consideration, in these foraminifers that generally have two apertures, apart from the number is the position of the apertures. It is known that, foraminifers show differences in the number, shape and position of their apertures (Loeblich and Tappan, 1964). Yet, secondary aperture(s) are found in foraminifers as an addition to the single aperture, and the position of this secondary aperture is fixed for each genus and specimen. (Loeblich and Tappan, 1964) Some of our samples have two apertures (Pl. 1, figs. 3-6; Pl. 2, figs.6,7; $\mathrm{Pl}$. 3, fig. 3); some have three apertures (Pl. 1, fig. 14); some have four apertures (Pl. 1, fig. 9; Pl. 2, figs. 3-5) and some have five apertures (Pl. 3, figs. 4-6). In this last sample, it was impossible to envision it as a whole in the electron microscope due to the fact that all of these five apertures are located in different positions. It was envisioned in a normal binocular microscope with computer support. Another thing is that even though the positions of the primary aperture and the secondary aperture(s) is fixed (Loeblich and Tappan, 1964), Cibicidella variabilis (d'Orbigny) 
specimens show irregularities in the positions of the apertures although the shapes of the apertures carry similar characteristics, which contradicts to the general information on foraminifers. Yet, the difference in the test structures in the younger specimen proves the presence of a different and specific characteristic of the mentioned genera and species.

According to some researchers, the reason of the morphological abnormalities seen in foraminifer tests can be pollution, especially the different test structures of Rosalina globularis d'Orbigny, Lobatula lobatula (Walker and Jacob) and Planorbulina mediterranensis d'Orbigny and different Ammonia and Elphidium specimen result from the fact that the plane that these specimens are attached are not straight and regular. (Sharifi et al., 1991, Stouff et al., 1999, Geslin et al., 2000 and 2002, Yanko et al., 1994, 1998 and 1999) Also, researchers hypothesize that feeding difficulties may result in such morphological changes and in these cases some

\section{References}

Akyürek, B. (1989): M. T. A. Genel Müdürlüğü 1:100.000 ölçekli Açınsama Nitelikli Türkiye Jeoloji Haritaları Serisi Ayvalık-G3 Paf, 8 p.

Almogi-Labin, A., Perelis-Grossowicz, L. And Raab, M. (1992): Living Ammonia from a hypersaline inland pool. Dead Sea Area, Israel. Journal of Foraminiferal Research, 22 (3): 257-266.

Alve, E. (1991): Benthic foraminifera in sediment cores reflecting heavy metal pollution in Sorfjord, western Norway. Journal of Foraminiferal Research, 21 (1): 1-19.

Arpat, E. and Şaroğlu, F. (1975): Türkiye'deki bazı önemli genç tektonik olaylar. Türkiye Jeoloji Kurumu Bülteni, 18: 91-101.

Artüz, M. I. (1970): Some observations on the hydrography of the Turkish Aegean waters during 4-25 September 1963. Publications of the Hydrobiological Research Institute, Faculty of Science, University of Istanbul, Serie B, 1-9. abnormal developments can occur. Furthermore, some researchers connect the changes in test structures with pollution and environmental stress. Yet, Geslin et al. (1998) discus that apart from the corruption of the crystal structure due to stress as a result of the effect of the trace elements in the environment that the organisms live in, the other chemical and physical changes in the environment and shortage of food can also cause such different shapes.

\section{Conclusion}

As a result, the main reason of the abnormal morphological changes observed in the tests of Cibicidella variabilis (d'Orbigny) specimen that are very frequently seen in Turkish coasts of the East Aegean Sea, can be the presence of some trace elements in abnormal quantities in the submarine thermal springs in the region, as also discussed briefly by Geslin et al. (1998). Yet, it can also be discussed that biological characteristics, apart from the physical and chemical environmental conditions, also have an effect on the morphological changes in the tests.

Avşar, N. and Meriç, E. (2001): Çeşme-Ilıca Koyu (Izmir) termal bölgesi güncel bentik foraminiferlerinin sistematik dağılımı. H. Ü. Yerbilimleri, 24: 13-22, Ankara.

Barut, I.F. (2001): Milas-Ekinambarı ve Savran Tuzlu Kaynaklarının Hidrokimyasal Araştırması, İ.Ü. Fen Bilimleri Enstitüsü, Ph.D. Thesis, (unpublished), 189p.

Başkan, E. and Canik, B. (1983): Türkiye sıcak ve mineralli sular haritas1, Ege Bölgesi. Maden Tetkik ve Arama Enstitüsü Yayınları, 189: 80 p., Ankara.

Benli, H. and Küçüksezgin, F. (1988): Ulusal Deniz Ölçme ve İzleme Programı, Ege Denizi Ölçme ve İzleme Alt Projesi 1988 Dönemi Kesin Raporu. Reports of the Institute of Marine Sciences and Tecnology, Dokuz Eylül University, 281 p., İzmir.

Blanc-Vernel, L., Clainefond, P. And Orsoloni, P. (1979): Etude des organismes: Les foraminiferes. In: La Mer Pélagienne. Annales de l'Université de Provence-Géolgie Méditerranéenne, 6 (1) : 171-209, Marseille. 
Boltovskoy, E., Scott, D. B., and Medioli, F. S. (1991): Morphological variations of benthic foraminiferal tests in response to changes in ecological parameters: A review. Journal of Paleontology, 65 (2): 175-185.

Cimerman, F. and Langer, M.R. (1991): Mediterranean foraminifera. Slovenska Akademija Znanosti in Umetnosti. Academia Scientiarum et Artium Slovenca. Ljubljana. 118 p., 93 plts.

Colom, G. (1974): Foraminiferos Ibéricos. Introduction al estudio de las especies benthonicas recientes. Investigacion pesquera. 38 (1): 1-245, plts. 1-69, Barcelona.

Cushman, J. A. (1931): The foraminifera of the Atlantic Ocean, Pt. 8. Rotaliidae, Amphisteginidae, Calcarinidae, Cymbaloporettidae, Globorotaliidae, Anomalinidae Planorbulinidae, Rupertiidae and Homotremidae. Bulletin of United States Natural Museum, Washington. 104 (8): 1179, plts. 1-26.

Çağlar, K. Ö. (1946) Türkiye maden suları ve kaplıcaları. Maden Tetkik ve AramaEnstitüsü Yayınları, Seri B, no. 11, 791 p., Ankara.

Çağlar, K. Ö. (1947) Türkiye Maden Suları ve Kaplicaları. Maden Tetkik ve Arama Enstitüsü Yayınları, Seri B, 11: 94 p., Ankara.

Debenay, J.-P., Geslin, E., Eicher, B. B., Duleba, V., Sylvestre, F. and Eicher, P. (2001): Foraminiferal assemblages in a hypersaline lagoon, Araruama (R.J.) Brazil. Journal of Foraminiferal Research, 31 (2): 133-151.

Dezelic, V. (1896): Foraminifera Jadranskog mora. Glasnik Hrvatskog naravoslog drustva, 9: 1-97, Zagreb.

Dora, Ö. O. and Savaşçin. Y. M. (1980): AlibeyMaden adaları (Ayvalik) bölgesi magmatizmasi. TÜBİTAK Bilim Kongresi Bildiriler Kitabı, 11-33.

Ekmekçi, M. (2005): Pesticide and nutrient contamination in the Kestel polje-Kirkgoz karst springs, Southern Turkey. Environmental Geology, 49: 19-29.
Elberling, B., Knudsen, K. L., Kristansen, P. H. and Asmund, G. (2003): Applying foraminiferal stratigraphy as a biomarker for heavy metal contamination and mining impact in a fiord in West Greenland. Marine Environmental Research, 55: 235-256.

Ergin, M., Bodur, M.N., Ediger, V., Yemenicioğlu, S., Okyar, M. and Kubilay, N. (1993): Sources and dispersal of heavy metals in surface sediments along the Eastern Aegean Shelf. Bolletino Di Oceanologia: Teorica Ed Applicata, 11 (1): 27-44.

Ergin, M. and Yemenicioğlu, S. (1997): Geologic Assessment of Environmental Impact in Bottom Sediments of the Eastern Aegean Sea. International Journal of Environmental Studies, 51: 323-334.

Evans, G. (1971): The Recent sedimentation of Turkey and the adjacent Mediterranean and Black seas: a review. In: Geology and history of Turkey, Campbell A.S. (Ed.), Pet. Explor. Soc. Libya, 385-406.

Geslin, E., Debenay, J. P. and Lesourd, M. (1998): Abnormal wall textures and test deformation in Ammonia (Hyaline foraminifer). Journal of Foraminiferal Research, 28 (2): 148-156.

Geslin, E., Stouff, V., Debenay, J. P. and Lesourd, M. (2000): Environmental variation and foraminiferal test abnormalities. Environmental Micropaleontology, volume 15 of Topics in Geobiology, edited by R., E. Martin, Kluwer Academic/Plenum Publishers, New York, 191-215.

Geslin, E., Debenay, J.-P., Duleba, W., and Bonetti, C. (2002). Morphological abnormalities of foraminiferal tests in Brizalian environments; comparison between polluted and non-polluted areas. Marine Micropaleontology, 45: 151-168.

Hallock, P. (1984) Distribution of selected species of living algal symbiont-bearing foraminifera on two Pacific Coral Reefs. Journal of Foraminiferal Research, 14 (4): 250-261.

Krauskopf, K.B. (1985): Introduction to Geochemistry, 2nd Edition, McGraw-Hill Int. Series in the Earth and Planetary Sciences, $550 \mathrm{p}$. 
Langer, M. (1988): Recent epiphytic foraminifera from Vulcano (Mediterranean Sea). Revue de Paléobiologie, Benthos'86, Geneve, 827-832.

Le Calvez, Y. (1974): Révision des Foraminiferes de la collection d'Orbigny I. Foraminiferes des iles Canaries. Cahiers de Micropaléontologie, Paris, 1974 (2): 1-108, plts. 1-28.

Loeblich, A. R. and Tappan, H. (1964): Treatise on Invertebrate Paleontology. Part C, Protista 2, Sarcodina. Vol.1 and 2, 890 p. (Edited by R.C.Moore).

Loeblich, A. R. and Tappan, H. (1988): Foraminiferal genera and their classification. 2 vols., Van Nostrand Reinhold Company, New York, 1-970, plts. 1-847.

Mascle, J. and Martin, L. (1990): Shallow structure and recent evolution of the Aegean Sea: A synthesis based on continuous reflection profiles. Marine Geology, 97: 271299.

Mckenzie, D.P. (1977): Can plate tectonic describe continental deformation?, In: Structural history of the Mediterranean Basins. (Biju-Dual, B., Montadert, L., Ed.), Editions Technip, Paris, 189 p.

Meriç, E. (1986): Deniz dibi termal kaynakların canlı yaşamına etkisi hakkında güncel bir örnek (Ilıca-Çeşme-Izmir). Türkiye Jeoloji Kurumu Bülteni, 29 (2): 17-21.

Meriç, E. and Avşar, N. (2001): Benthic foraminiferal fauna of Gökçeada Island (Northern Aegean Sea) and its local variations. Acta Adriatica, 42 (1): 125-150.

Meriç, E., Avşar, N. and Bergin, F. (2002a): Midilli Adası (Yunanistan-Kuzeydoğu Ege Denizi) bentik foraminifer faunas1 ve bu toplulukta gözlenen yerel değişimler. Çukurova Üniversitesi Yerbilimleri, 40-41: 177-193.

Meriç, E., Avşar, N. and Nazik, A. (2002b): Bozcaada (Kuzey Ege Dnizi) bentik foraminifer ve ostrakod faunası ile toplulukta gözlenen yerel değişimler. Çukurova Üniversitesi Yerbilimleri, 40-41: 97-119.
Meriç, E., Görmüş, M., Avşar, N. and Ünsal, I. (2002c): Güncel nodosariid bentonik foraminiferlerde üreme sırasındaki anormal oluşumların önemi ve rastlantı faktörü. Türkiye Petrol Jeologları Derneği Bülteni, 14 (1): 67-82, Ankara.

Meriç, E., Avşar, N., Görmüş. M. and Orak, H., (2002d): Saros Körfezi (Kuzey Ege Denizi) Harmantaşı mevkii sualtı yükseltisi çevresinin foraminifer faunası ile bu alandaki kaynakların canlı yaşamına etkisi hakkında ön bulgular. Sualtı Bilim ve Teknoloji Toplantıs1 (SBT) Bildiriler Kitab1, 182-193.

Meriç, E., Avşar, N., Bergin, F. and Barut, I. F. (2003a): A note three abnormal samples of benthic foraminifers from the Dikili Bay (Turkey) in northeastern Aegean Sea: Peneroplis planatus (Fichtel and Moll), Rosalina sp. and Elphidium crispum (Linné). Bulletin of the Mineral Research and Exploration, 127: 1-14.

Meriç, E., Avşar, N., Bergin, F. and Barut, I.F. (2003b): Edremit Körfezi (Kuzey Ege Denizi, Türkiye) çökellerindeki bentik foraminifer topluluğu ile ekolojik koşulların incelenmesi. Çukurova Üniversitesi. Yerbilimleri, 43: 169182.

Meriç, E., Avşar, N. and Bergin, F. (2004a): Benthic foraminifera of Eastern Aegean Sea (Turkey), systematics and autoecology. Chamber of Geological Engineers of Turkey and Turkish Marine Research Foundation Publication 18: , 310 p., 33 pls., İstanbul.

Meriç, E., Avşar, N., Nazik, A., Eryilmaz, M. and Yücesoy-Eryilmaz, F. (2004b) Saros Körfezi'nin (Kuzey Ege Denizi) güncel bentik ve planktik foraminifer toplulukları ile çökel dağılımı. Çukurova Üniversitesi Yerbilimleri (Geosound), 44-45: 1-44.

Meriç E., Avşar N., Nazik, A., Alpar, B., Yokeş, B., Barut İ.F. and Ünlü, S. (2005a): Gemlik Körfezi yüzey çökellerinin Foraminifer, Ostrakod ve Mollusk faunas1, foraminifer kavkılarında gözlenen morfolojik anomaliler ile bölgenin sedimantolojik, hidrokimyasal ve biokimyasal özellikleri. Maden Tetkik ve Arama Dergisi, 131: 21-48, Ankara. 
Meriç, E., Görmüş, M., Nielsen, J.K., Avşar, N. and Ünsal, İ. (2005b): Significance of rare reproduction occurence among recent Nodosariids and other benthic foraminifera. Anales De Biologia, 27: 85-100.

Meriç, E., Avşar, N., Yokeş, B., Tuğrul, A. B., Bayari, S., Özyurt, N., Barut, İ. F., Balkis, N., Uysal, K., Kam, E. (2008a): Morphological abnormalities in benthic foraminifers of the Antalya coast. Micropaleontology, 54 (3-4): 241-276.

Meriç, E., Avşar, N., Nazik, A., Tunoğlu, C., Yokeş, B., Barut, İ. F., Yücesoy-Eryilmaz, F., Tuğrul, B., Görmüş, M., Öncel, M. S., Orak, H., Kam, E. and Dinçer, F. (2008b): Harmantaşı Mevkii (Saros Körfezi-Kuzey Ege Denizi) deniz içi kaynakları çevresindeki foraminifer ve ostrkaod topluluğuna bu alandaki çevresel koşulların etkisi. Maden Tetkik ve Arama Dergisi (in Turkish), 136: 63-84, Ankara.

Meriç, E., Avşar ,N., Mekik, F., Yokeş, B., Barut, İ.F., Dora, Ö., Suner, F., Yucesoy, Eryilmaz, F., Eryilmaz, M., Dincer, F. and Kam, E. (2009): Abnormal tes formations observed in the benthic foraminifers from recent sediments of Alibey and Maden 1slands (Ayvalık, Balıkesir). Geological Bulletin of Turkey. 52 (1): 31-84 (in Turkish with extended English summary).

Meriç. E., Yokeş, M.B., Avşar, N., Dinçer, F. (2015): New Observations of Alien Foraminifera on the Turkish Coasts of the Aegean Sea (2008-2011). International Journal of Environment and Geoinformatics. 2 (2): 77-87

Meriç. E., Yokeş, M.B., Avşar, N., Dinçer, F. (2016): New Observations of Alien Foraminifera on the Turkish Coasts of the Aegean Sea (2012-2015). International Journal of Environment and Geoinformatics. 3 (1): $44-47$

MTA. (1989): Known ore and mineral deposits of Turkey. Publications of General Directorate of Mineral Research and Exploration Institute, 185: 108 p., Ankara
Nigam, R., Saraswat, R. and Kurtarkar, S. R. (2006): Laboratory experiment to study the effect of salinity variations on benthic foraminiferal species - Pararotalia nipponica (Asano). Journal Geological Society of India, 67: 41-46.

Orbigny, A. D. L'. (1839): Foraminiferes. In: P. Barler-Webb and S. Berthelot: Histoire naturelle des Iles Canaries. 11 (2) : Zoologie, 119-146, plts. 1-3, Paris: Bethune.

Sellier De Civrieux, J.M. (1970): Mutaciones recientes del género Peneroplis y relaciones filogénicas con otros Soritidae, Revista Espanola de Micropaleontologia, 11(1) : 5-12.

Sgarrella, F. and Moncharmont-Zei, M. (1993): Benthic Foraminifera of the Gulf of Naples (Italy): systematics and autoecology, Modena. Bolletino della Societa Paleontologica Italiana, 32 (2): 145-264.

Sharifi, A. R. L., Croudace, W. and Austin, R. L. (1991): Benthic foraminiferids as pollution indicators in Southampton Water, southern England. United Kingdom. Journal Micropaleontology, 10 (1): 109-113.

Sözeri, B. (1966): İzmir, Çeşme Ilıcası plaj kumundaki aktüel foraminiferler ve variasyonları, Türkiye Jeoloji Kurmu Bülteni, 10 (1-2): 143-154, Levha1-6.

Stouff, V., Geslin, E., Debenay, J. P. and Lesourd, M. (1999): Origine of morphological abnormalities in Ammonia (Foraminifera): Studies in laboratory and natural environments. Journal of Foraminiferal Research, 29 (2): 152-170.

Şengör, A.M.C. and Yilmaz, Y. (1981): Thethyan evolution of Turkey: a plate tectonic approach. Tectonophysics, 75: 181-241.

Thiermann, F., Akoumianaki, I., Hughes, J. A. and Giere, O. (1997): Benthic fauna of shallow-water gaseohydrothermal vent area in the Aegean Sea (Milos, Greece). Marine Biology, 128 (1): 149-159.

Turgut, S. (1987): Report on the Paleogeographic Development of Aegena Sea. TPAO, Ankara. 
Türkiye Maden Sulari (3), Ege Bölgesi. (1974): Istanbul Üniversitesi, Tıp Fakültesi HidroKlimatoloji Kürsüsü, 335 p., Istanbul.

Türkiye Mineralli Su Kaynaklari I (Ege Bölgesi). (1999): Istanbul Üniversitesi, Tıp Fakültesi Tıbbi Ekoloji ve Hidro-Klimatoloji Anabilim Dalı, I.Ü. Araştırma Fonu Projesi (unpublished report), 119 p., Istanbul.

Varnavas, S. P., Halbach, P., Halbach, M., Panagiotaras, D., Rahders, E. and Hubner, A. (1999): Characterization of hydrothermal fields and hydrothermal evolution in the Hellenic Volcanic Arc. International Conference of the Eastern Mediterranean and Black Sea. Athens, Greece, Abstracts, 343.

Yalçin, H., Meriç, E., Avşar, N., Bozkaya, Ö. and Barut, I. F. (2004): Geochemical anomalies in the recent foraminifers of İskenderun Bay. Geological Bulletin of Turkey, 47 (2): 25-39 (in Turkish, English abstract and extended summary), Ankara.

Yalçin, H., Meriç, E., Avşar, N., Tetiker, S., Barut, İ. F., Yilmaz, Ş. and Dinçer, F. (2008): Mineralogical and geochemical features of colored benthic foraminifers from Aegean and southwestern coasts of Turkey. Micropaleontology, 54 (3-4): 351-370.
Yanko, V., Kromfield, J. and Flexer, A. (1994): Response of benthonic foraminifera to various pollution sources: Implication for pollution monitoring. Journal of Foraminiferal Research, 24: 1-17.

Yanko, V., Ahmad, M. and Kaminsky, M. (1998): Morphological deformities of benthic foraminiferal tests in response to pollution monitoring. Journal of Foraminiferal Research, 28 (3): 177-200.

Yanko, V., Arnold, A. and Parker, W. (1999): The effect of marine pollution on benthic foraminifera: in: Modern Foraminifera, Sen Gupta, B., Ed., Kluwer Academic Publishers, $384 \mathrm{p}$.

Yilmaz, Y. (1990): An approach to the origin of young volcanic rocks of Western Turkey. Tectonic evolution of the Thethyan region, (Ed. Şengör, A.M.C.), Kluwer Academic Publication, 159-189.

Yokeş, M.B., Meriç, E., Avşar, N., Barut, İ., Tas, S., Eryilmaz, M., Dinçer, F. and Bircan, C. (2014): Opinions and comments on the benthic foraminiferal assemblage observed around the mineral submarine spring in Kuşadası (Aydın, Turkey). Marine Biodiversity Records, 7: e103, doi:10.1017/S1755267214000840. 


\section{PLATE 1}

Cibicidella variabilis (d'Orbigny).

1. Spiral side, x 90, station 1, Gulf of Edremit.

2. Edge view, x 80, station 1, Gulf of Edremit.

3. Umblical side, x 35, station 6, Gulf of Edremit.

4. Spiral side, x 60, station 8, Dikili Bay.

5. Spiral side, $\mathrm{x} 43$, station 8, Dikili Bay.
6. Spiral side, x 55, station 8, Dikili Bay.

7. Spiral side, $x$ 60, station 8, Dikili Bay.

8. Spiral side, $x$ 50, station 8, Dikili Bay.

9. Spiral side, $x$ 55, station 8, Dikili Bay.

10. Umblical side, $\mathrm{x} 95$, station 8, Dikili Bay.

11. Umblical side, $x$ 70, station 5, Dikili Bay.

12. Umblical side, $\mathrm{x} 60$, station 6 , Gulf of Gökova.

13. Edge view, x 60, station 6, Gulf of Gökova.

14. Umblical side, $x$ 40, station 6 , Gulf of Gökova

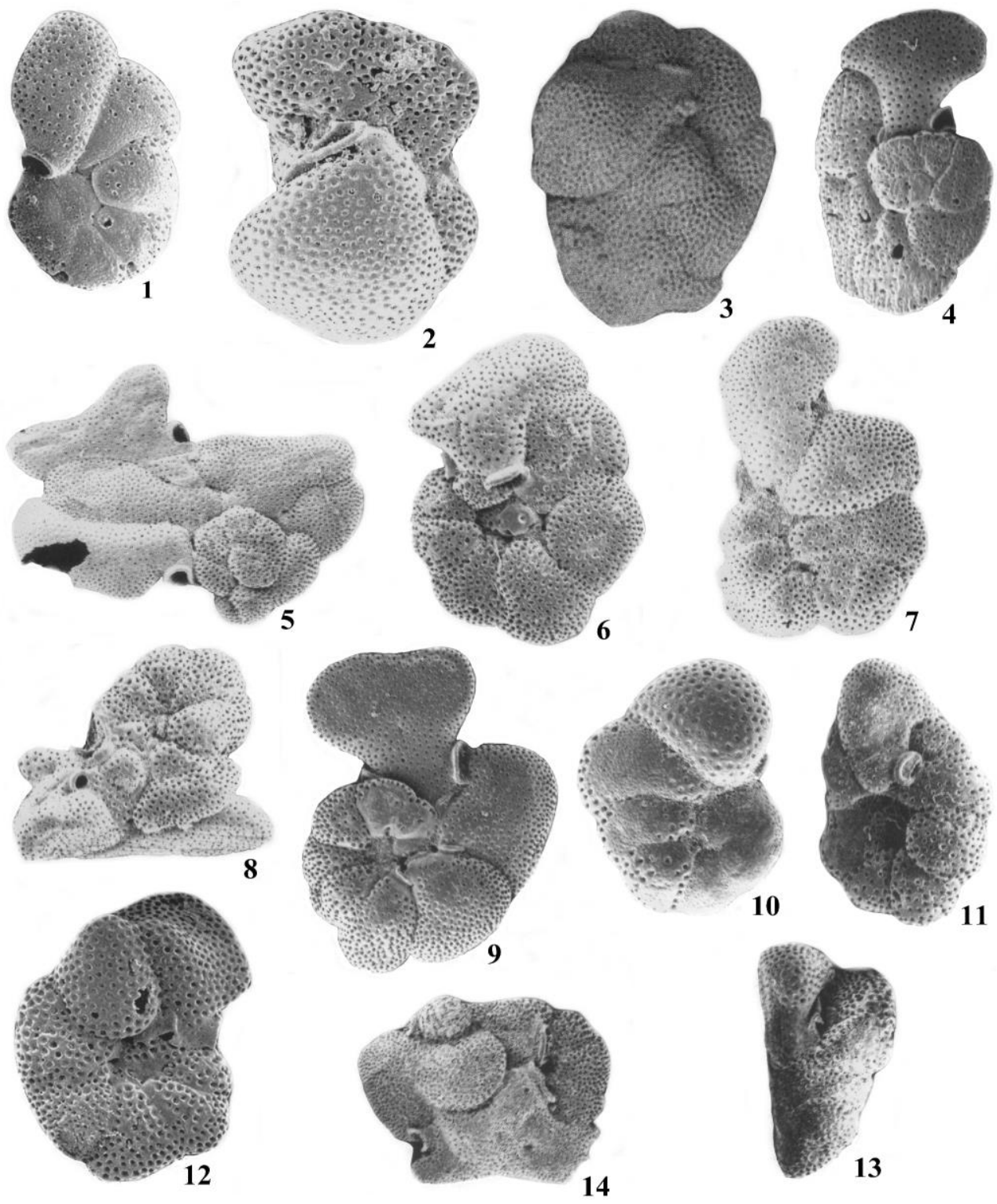




\section{PLATE 2}

Cibicidella variabilis (d'Orbigny).

1. Umblical side, x 56, station 2, Gulf of Gökova.

2. Umblical side, $\mathrm{x} 41.5$, station 6 , Gulf of Gökova.

3. Umblical side, x 22.5, station 2, Gulf of Gökova.

4. Detail view of the two apertures, $x$ 137, station 2, Gulf of Gökova.

5. Detail view of the other two apertures, x 145, station 2, Gulf of Gökova.

6. Spiral side, x 37, station 6, Gulf of Gökova.

7. Umblical side, x 36, station 5, Gulf of Datça.

8. Umblical side, x 50, station 4, Gulf of Datça.

9. Spiral side, $x$ 41, station 4, Gulf of Datça.

10. Spiral side, x 28, station 37, Gulf of Kuşadas1.

11. Spiral side, $\mathrm{x} 41.5$, station 37, Gulf of Kuşadas1.

12. Spiral side, $x 27.5$, core $2 \mathrm{c}$, Ayvalık.

13. Spiral side, $x$ 32, core 2c, Ayvalık.

14. Umbilical side, $x$ 56, core 2c, Ayvalık.
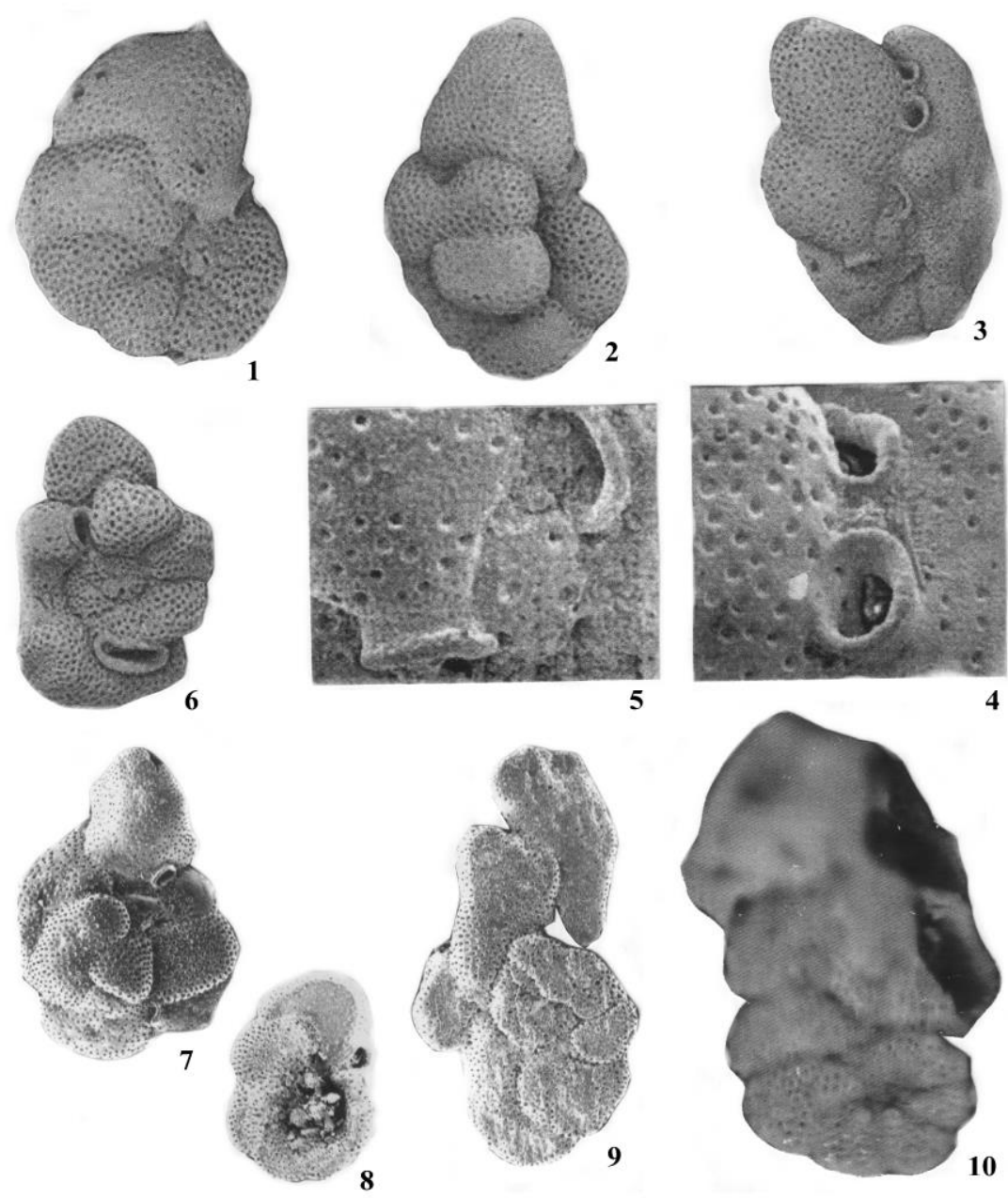


\section{PLATE 3}

Cibicidella variabilis (d'Orbigny).

1. Spiral side, x 33, station 5, Vicinity of Karaburun Peninsula, Çeşme-İzmir.

2. Individual with one aperture, $x 70$, station 5, Vicinity of Karaburun Peninsula, İzmir.

3. Individual with two apertures, $x$ 25, station 8, Dikili Bay.

4. Three apertures of an individual with five apertures, $\mathrm{x} 49$, station 8, Dikili Bay.

5. Another aperture of the same individual, $x$ 22, station 8, Dikili Bay.

6. Another aperture of the same individual, x 56, station 8, Dikili Bay.

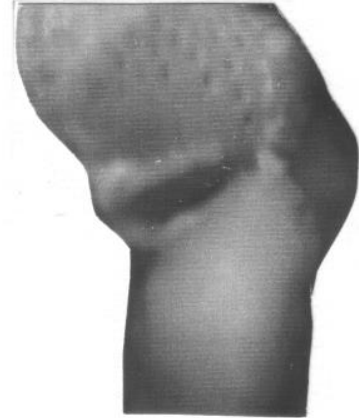

1
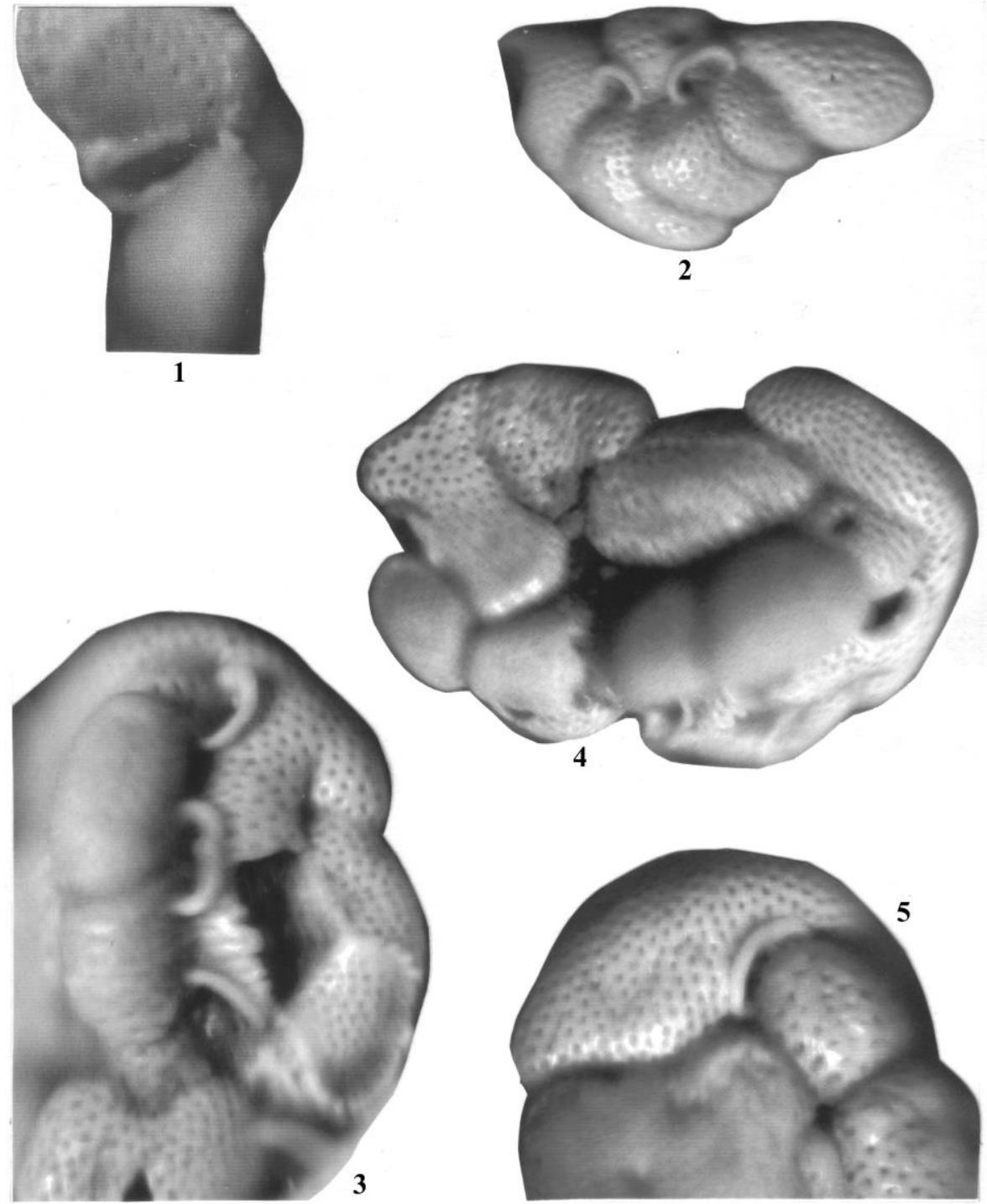